\title{
メタノール熱分解ガスを用いた火花点火機関における 燃焼室内空気流動および排気再循環の影響*
}

\author{
首藤 登志夫*1, 岩 崎 秀 之年, 俵 山亮 $太^{* 3}$
Influence of In-cylinder Air Motion and Exhaust Gas Recirculation on Combustion of Methanol-Reformed Gas in an SI Engine \\ Toshio SHUDO*4, Hideyuki IWASAKI and Ryota TAWARAYAMA \\ *4 Department of Mechanical Engineering, Kitami Institute of Technology, \\ 165 Koencho, Kitami-shi, Hokkaido, 090-8507 Japan

\begin{abstract}
This research analyzed characteristics of combustion and emissions in a spark-ignition internal combustion engine fueled with methanol-reformed gas. Experiments were done with a model gas with $67 \%$ of hydrogen and $33 \%$ of carbon monoxide that corresponds to the thermally decomposed methanol. This research cleared influences of in-cylinder air motion by swirl on thermal efficiency and exhaust emissions. While the enhanced air motion is effective to improve the combustion efficiency, it simultaneously increases the heat transfer from burning gas to the combustion chamber wall. Because of this, the thermal efficiency decreases in some cases. Influence of EGR on $\mathrm{NO}_{x}$ emission and thermal efficiency in the combustion was also analyzed in this research.
\end{abstract}

Key Words: Methanol-Reformed Gas, Hydrogen, Swirl, EGR, Combustion, Thermal Efficiency, Cooling Loss

\section{1. 緒言}

炭化水素やアルコールを改質したガスを燃料に用い る内燃機関では，機関排気熱を燃料の改質反忘に利用 することが可能であるため，排熱回収による高い総合 システム効率が期待できる．とくにメタノールを用い る場合には，熱分解反応に要する温度が比較的低いこ とから,メタノール熱分解ガスを用いた内燃機関につ いての研究がこれまでにいくつか報告されている(1)-(5).

メタノールの熱分解ガスは, 水素2モルと一酸化炭素 1モルから成るガスである．水素は広い可燃混合比範囲 を持ち，希薄燃焼においても比較的高い燃焼速度を維 持できる．また，水素が共存することで一酸化炭素の 着火性は大きく向上する(6)ため, 両者が共存するメタ， 一ル熱分解ガスを内燃機関に用いる場合には希薄燃焼 による高い熱効率が期待できる.

希薄混合比条件での燃焼状態を改善する方法のひと つとして，スワールやタンブルなどによる燃焼室内空 気流動の利用がある。しかし，火炎伝播速度が大きい ために燃焼過程での筒内ガスの対流が強い水素の燃焼 においては, 燃焼ガスから燃焼室壁面への熱伝達によ

* 原稿受付 2004 年1月 23 日.

*1 正員, 北見工業大学工学部(更 090-8507 北兒市公園町 165).

*2 元: 武蔵工業大学大学院工, 学研究科

*3 日産工機(株) (一253-0105 神奈川県高座郡寒川町岡田 6).

E-mail : shudoto@ mail.kitami it.ac.jp
る冷却損失割合が大きいことが分かっており(7)-(9)，水 素を含むメタノール熱分解ガスの燃焼において空気流 動を強化した際の冷却損失の特性は興味深い.一方, メタノール熱分解ガスを用いた機関においては, 水素 を用いた場合と比べて熱効率が最高となる空気過剩率 が小さく, 熱効率に対する最適な空気過剩率で運転し た場合のNOx排出量が水素燃焼に比べて若干多いこと が分かっている(5). そのため, より希薄な混合比条件 での熱効率向上あるいは熱効率に対する最適な空気過 剩率でのNOx排出量の低減がメタノール熱分解ガスを 用いた機関において求められる.

本研究では, メタノール熱分解ガスを燃料に用いた 火花点火機関において, 燃焼室内空気流動の強化およ び排気再循環が燃焼, 排気, ならびに椧却損失を始め とする各種熱効率影響因子の特性に及ぼす影響につい て解析を行った.

\section{2. 実験装置および実験方法}

本研究には，図1に示すような自動車用4気筒4サイ クル火花点火機関 (ボア $\phi 89 \mathrm{~mm}$, ストローク $96 \mathrm{~mm}$, 圧縮比 14)を使用した。燃料ガスは,メタノールの熱 分解ガスを想定した水素67\%一酸化炭素33\%の模擬ガ スであり，ボンベよりレギュレータを介して吸気管内 に連続的に供給し, 予混合燃焼を行った. また, 比較 のために水素を燃料に用いた実験を一部の条件におい 
て行った。燃料ガス流量の測定には熱式気体質量流量 計(オーバル MAFLO-OVAL)を用いた. 実験において, シリンダーヘッドに取り付けたピエゾ式圧力変換器 (AVL GM12D)により燃焼圧力を計測し，各運転条件に つき20サイクル分のデータを平均した後に図示熱効率,

見かけの熱発生率および冷却損失割合などの解析を行 った. 排気中のNOx濃度の測定にはCLD式分析計, CO 濃度の測定にはNDIR式分析計， $\mathrm{O}_{2}$ 濃度の測定にはMPA 式分析計を用いた，燃焼室内空気流動の影響を調べる 際には，図2に示すようにスワール比制御プレートを機 関の吸気ポートと吸気マニフォールドの間に取り付け て実験を行った。これにより供試機関の燃焼室内に形 成されるスワール比は4.7である。なお全ての実験にお いて, 燃料ガスを含めた体積効率を $70 \%$, 機関回転速 度を2000rpmとした．また，排気再循環 (EGR)の影響を 調べる際には, クールドEGRガスを想定して, 窒素お よび二酸化炭素をボンベからニードル弁および流量計 を介して吸気管内に供給して実験を行った.

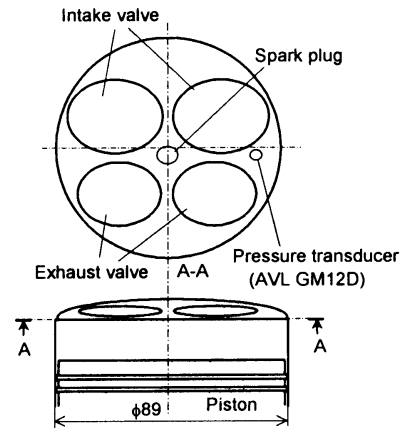

Fig.1 Combustion chamber of the tested engine

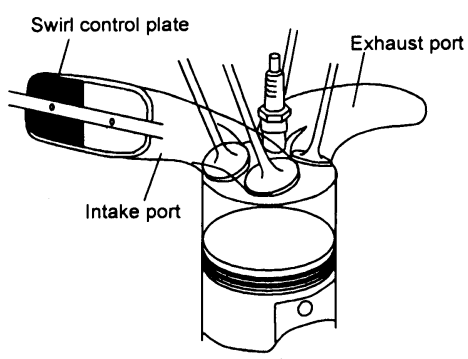

Fig.2 Layout of swirl control plate and ports

\section{3. 結果および考察}

$3 \cdot 1$ 水素燃焼との比較空気過剩率に対するメ夕 ノール熱分解ガス (MRG) 燃焼の特性を水素燃焼と比較 した実験結果を図3に示す．水素燃焼に比べると，メ夕 ノール熱分解ガス燃焼では熱効率が低く，その差は空
気過剰率入の増加とともに拡大寸る傾向があり，CO排 出濃度が同時に増加する。この際，何れの然料を用い た場合にも，空気過剩率の増加とともに最適点火時期 MBTが進角する傾向があるが，より大きな点火進角 がメタノール熱分解ガスの然焼においては必要であり， これらの結果にはメタノール熱分解ガスの然焼速度が 水素に比べて小さいことが影響を及ぼしていることが 考えられる.このため，メタノール熱分解ガスの然焼 においては図示熱効率 $\eta_{\mathrm{i}}$ が最高となる空気過剩率が水 素燃焼よりも小さく，機関を最適空気過剩率で運転し た場合のNOx濃度が若干高くなる。したがって、メタ ノール熱分解ガスを用いた機関において高熱効率と低 排気公害を実現するには，より希薄な混合比領域での 熱効率向上あるいは最適空気過剩率でのNOx排出量低 减が重要である。この目的のために, 燃焼室内空気流 動を利用することによる希薄混合比条件での燃焼状態 および熱効率への影響について, ならびに排気再循環 がNOx排出特性に与える影響について検討を行った。
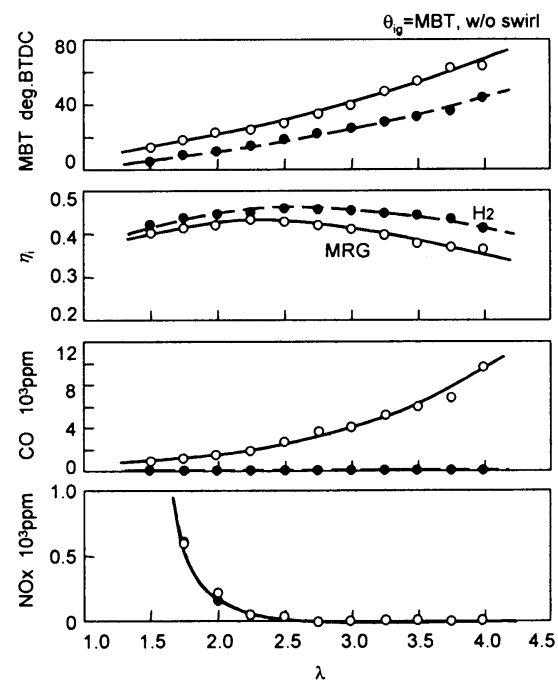

Fig. 3 Comparison of methanol reformed gas combustion and hydrogen combustion

$3 \cdot 2$ 燃焼室内空気流動の影譬 メタノール熱分 解ガスの燃焼においてスワールによる燃焼室内ガス 流動が熱効率および排気特性に及ぼす影響について 調べた実験結果を図4に示す．点火時期 $\theta_{\text {ig }}$ はそれぞれ の条件における最適点火時期MBTである，ここで発 熱等容度 $\eta_{\mathrm{glh}}$ は, Ottoサイクルの理論熱効率 $\eta_{\mathrm{th}}, 1$ サイ クルあたりの見かけの熱発生量 $Q$, 行程容積 $\mathrm{V}_{\mathrm{h}}$, 隙間 容積 $\mathrm{V}_{\mathrm{c}}$, クランク角 $\theta$ における筒内容積 $V$, 筒内ガスの 比熱比 $\gamma$ おび見かけの熱発生率 $\mathrm{d} Q / \mathrm{d} \theta$ を用いて以下の 
式により表される(8)(10).

$$
\eta_{\mathrm{glh}}=1 /\left(\eta_{\mathrm{th}} Q\right) \int\left(1-\left(\left(\mathrm{V}_{\mathrm{h}}+\mathrm{V}_{\mathrm{c}}\right) / V\right)^{1-\gamma}\right) \mathrm{d} Q / \mathrm{d} \theta \mathrm{d} \theta
$$

また，見かけの熱発生率 $\mathrm{d} Q / \mathrm{d} \theta$ は次式により算出し(9)， 得られた見かけの熱発生率 $\mathrm{d} Q / \mathrm{d} \theta$ を積分することで見か けの熱発生量 $Q$ を求めた.

$$
\begin{aligned}
\mathrm{d} Q / \mathrm{d} \theta= & V /(\gamma-1) \mathrm{d} P / \mathrm{d} \theta+\gamma P /(\gamma-1) \mathrm{d} V / \mathrm{d} \theta \\
& -P V /(\gamma-1)^{2} \mathrm{~d} \gamma / \mathrm{d} \theta
\end{aligned}
$$

図より，スワールによって希薄混合比での図示熱効率 $\eta_{\mathrm{i}}$ が増加することが分かる．これにより，図示熱効率が 最高となる空気過剩率が燃料希薄側へ移動し, 高熱効 率と低NOx排出が両立できる条件が存在することが分 かる，この際，CO排出濃度が低下するとともに発熱等 容度 $\eta_{\mathrm{glh}}$ が増加していることから，スワールによる燃焼 室内ガス流動の増加が燃焼速度および燃焼効率の向上 をもたらしたことが窥えるが，これらの改善効果は空 気過剩率の減少に伴って低下寸る傾向がある.

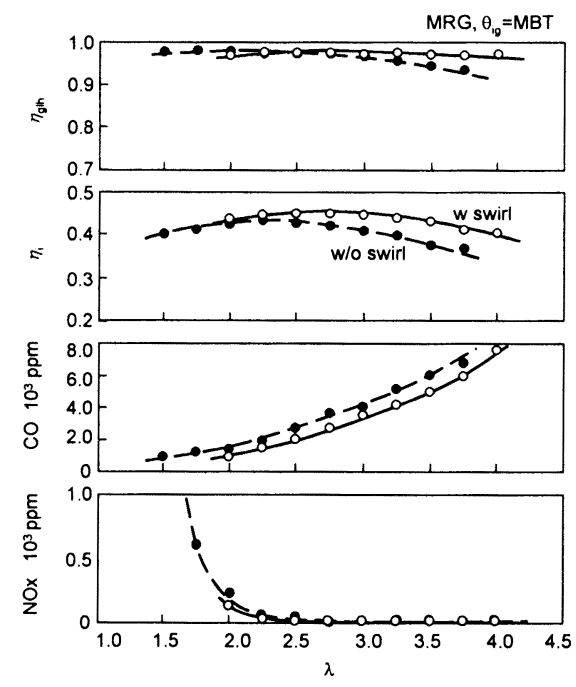

Fig.4 Influence of swirl on combustion of methanol reformed gas at $\mathrm{MBT}$ ignition timings

図5は，点火時期一定の元で，スワールの有無がメタ ノール熱分解ガス燃焼における筒内圧力 $P$, 見かけの熱

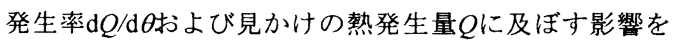
調べた結果である，設定した空気過剩率は $\lambda=2.0$ であり， 点火時期 $\theta_{\mathrm{ig}}$ はスワールが無い条件での最適点火時期 MBTである. 図より, スワールを導入した場合には, 見かけの熱発生率 $\mathrm{d} Q / \mathrm{d} \theta$ の上昇率が増加し燃焼期間が大 きく短縮しておりスワールによる燃焼室内の流動が然 焼速度を増加させる様子が明らかである. しかし同時

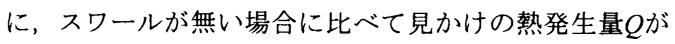

低下しており，空気流動の増加により燃焼速度だけで なく燃焼ガスから燃焼室壁面への熱伝達量も増加して いることが窥える。

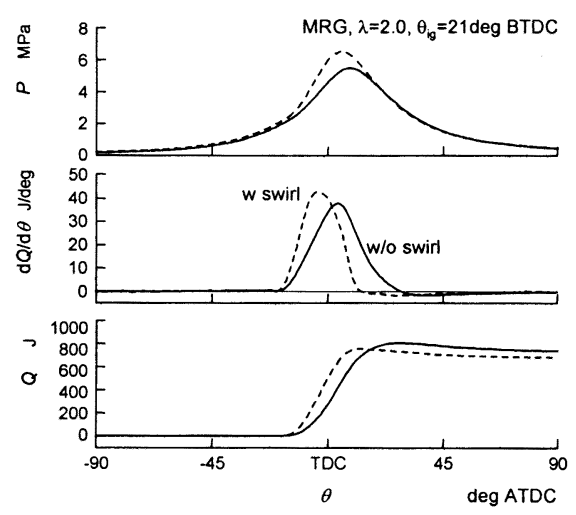

Fig.5 Indicator diagrams for combustion of methanol reformed gas with or without swirl

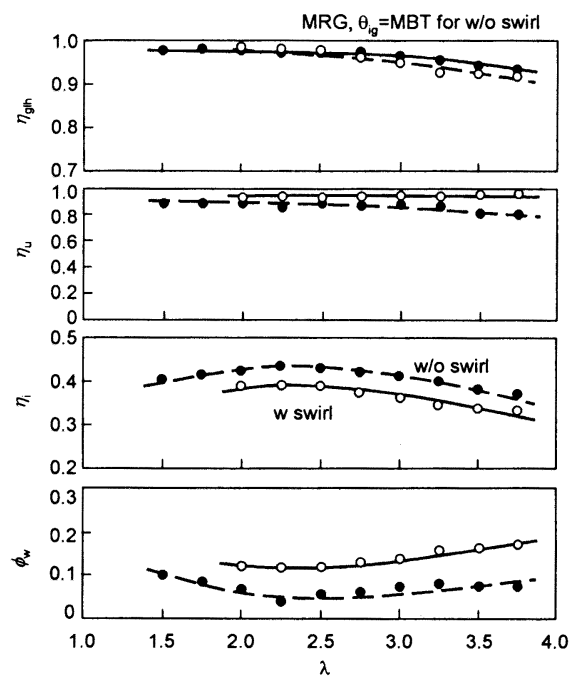

Fig.6 Influence of swirl on combustion of methanol reformed gas at fixed ignition timings

図6は，各空気過剩率において，スワールが無い場 合の最適点火時期MBTに点火時期を固定したまま で，スワールを導入した場合の熱効率影響因子を空気 過剩率に対して示している. 図は，図示熱効率 $\eta_{\mathrm{i}}$ とと もに発熱等容度 $\eta_{\mathrm{glh}}$, 燃焼効率 $\eta_{\mathrm{u}}$, 冷却損失割合 $\phi_{\mathrm{w}}$ を 解析した結果である. 燃焼効率 $\eta_{u}$ は排気中の $\mathrm{O}_{2}$ 濃度お よびCO濃度の計測値から算出し, 泠却損失割合 $\phi_{\mathrm{w}}$

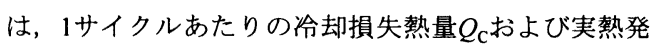
生量 $Q_{\mathrm{B}}$ により以下のように定義して求めた. 
$\phi_{\mathrm{w}}=Q_{\mathrm{C}} / Q_{\mathrm{B}}$

冷却損失熱量 $Q_{\mathrm{C}}$ は実熱発生量 $Q_{\mathrm{B}}$ よび見かけの熱発生 量 $Q$ を用いて以下のように表され,

$$
Q_{\mathrm{C}}=Q_{\mathrm{B}}-Q
$$

1サイクルあたりの実熱発生量 $Q_{\mathrm{B}}$ は, 1サイクルに供給 した燃料が持つ発熱量 $Q_{\text {fuel }}$ と燃焼効率 $\eta_{\mathrm{u}}$ の積で表せるた め, 冷却損失割合 $\phi_{\mathrm{w}}$ は次式により求められる

$$
\phi_{\mathrm{w}}=1-Q /\left(\eta_{\mathrm{u}} Q_{\text {fuel }}\right)
$$

図より，スワールの導入によって燃焼効率 $\eta_{u}$ が向上す るものの，冷却損失割合 $\phi_{\mathrm{w}}$ の大幅な増加のために図示 熱効率 $\eta_{\mathrm{i}}$ は低下寸る様子が分かる. 冷却損失割合 $\phi_{\mathrm{w}}$ の増 加から，空気流動の強化およびそれに伴う燃焼促進に よる火炎伝播速度の増加が燃焼ガスと燃焼室壁面との 間の熱伝達を促進したことが考えられる。 また，図5か ら分かるように, 点火時期を固定したままでスワール を導入した場合には，燃焼期間の短縮により熱発生の 重心が進角することで筒内最高圧および筒内ガス平均

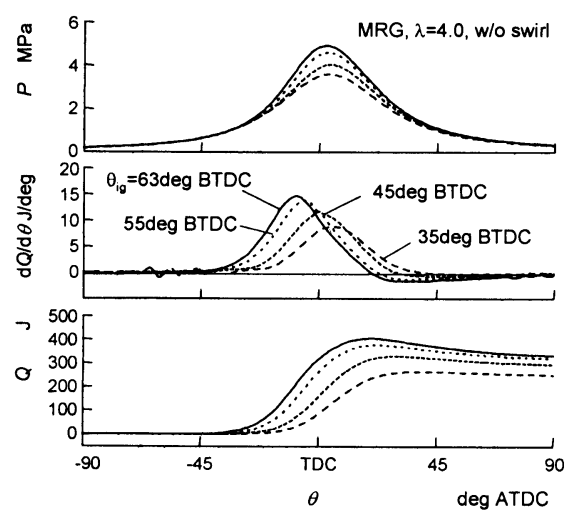

(a) Without swir
温度の最大值が増加することも熱伝達量の増加をもた らしていることが考えられる，そのため，スワールを 導入した場合には，熱効率に対する最適な点火時期が 遅角する. なお, 大幅に希薄な混合比条件において, 空気過剩率の増加に伴って冷却損失割合 $\phi_{\mathrm{w}}$ が増加する 傾向がある，これは，混合気の希薄化に伴って，実熱 発生量 $Q_{\mathrm{B}}$ はほぼ一様に減少するのに対して, 燃焼速 度低下に伴う最適点火時期進角により燃焼ガスから燃 焼室壁面への熱伝達が生じる期間が増加すること等の ために, 冷却損失熱量 $Q_{\mathrm{C}}$ の減少率が実熱発生量 $Q_{\mathrm{B}}$ の 減少率に比べて小さいことによるものと考えられる． $3 \cdot 3$ 点火時期特性への影䪪 空気過剩率 $\lambda=4.0$ の大 幅な希薄混合比条件において，スワールの導入がメ夕 ノール熱分解ガス燃焼の熱発生率特性に及ぼす影響に ついて点火時期をパラメータとして調べた結果を図7 に示す．スワールにより燃焼期間が短縮し，同時に見 かけの熱発生率 $\mathrm{d} Q / \mathrm{d} \theta$ の最大值が増加している. また，

Fig.7 Indicator diagrams for methanol reformed gas at different ignition timings

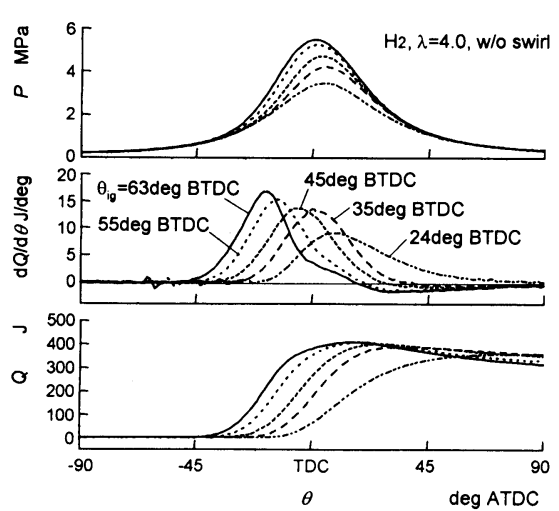

(a) Without swirl

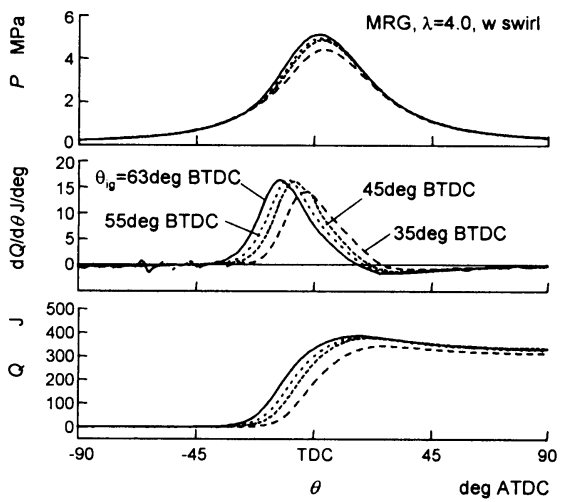

(b) With swirl

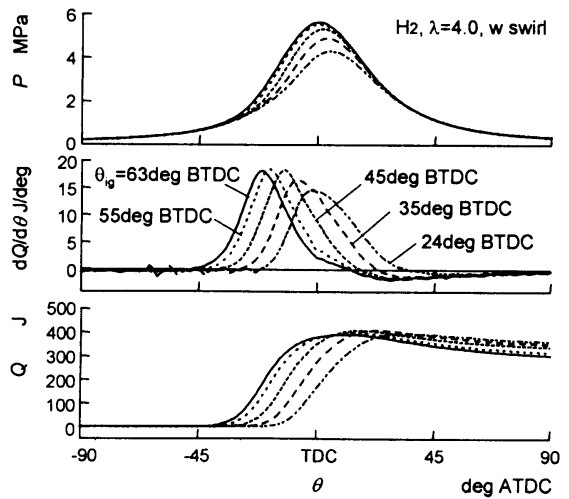

(b) With swirl 


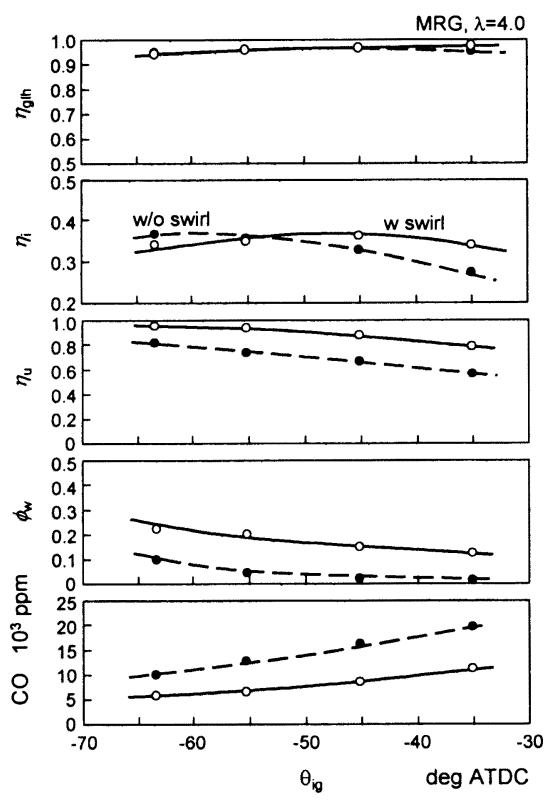

(a) Methanol-reformed gas

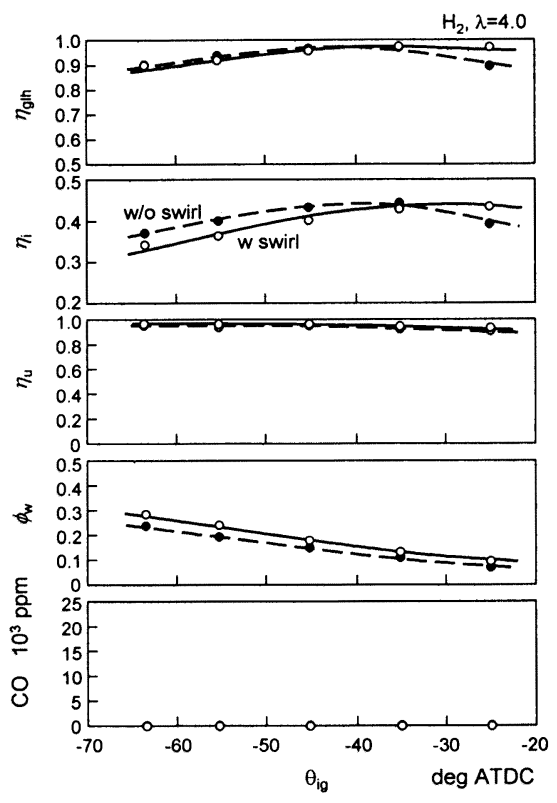

(b) Hydrogen

Fig. 9 Influence of swirl on thermal efficiency factors and $\mathrm{CO}$ emission

点火時期荤角側において見かけの熱発生量 $Q$ の最大值が 大幅に増加しており，然焼効率の著しい向上が窥える. 図8は，比較のために行った水素燃焼における同様の実 験の結果である。メタノール改質ガス燃焼の場合と同 様に，スワールにより燃焼期間が短縮するとともに見 かけの熱発生率 $\mathrm{d} Q / \mathrm{d} \theta$ の最大值が増加しているが，スワ 一ルを導入しない場合にも燃焼効率が高い水素燃焼で は見かけの熱発生量 $Q$ の最大值の増加は小さい.

以上の結果に対して，スワールが発熱等容度 $\eta_{\mathrm{glh}}$ およ び冷却損失割合 $\phi_{w}$ などの熱効率影響因子に与える影響 を解析した結果を，CO排出嶩度とともに図9に示す. 水素燃焼においてはスワールが存在しない場合にも燃 焼効率 $\eta_{\mathrm{u}}$ が比較的高いため, スワールによるその改善 は殆ど見られない，発熱等容度 $\eta_{\mathrm{glh}}$ は点火時期の遅角に 伴い低下寸る傾向があるが，スワールによってその低 下が抑えられる。 この発熱等容度の增加により, 点火 時期遅角側において図示熱効率が向上し, 最適点火時 期MBTが遅角側に移動している. また，進角側ではス ワールにより熱効率が低下寸る傾向があるが，これに は，燃焼室内の流動の增加に伴う冷却損失の増大が影 響していることが考えられる。一方，メタノール改質 ガス燃焼では，スワールにより燃焼効率 $\eta_{\mathrm{u}}$ が大きく増 加しており，CO排出量が減少している。この大幅な燃 焼改善にもかかわらず，点火時期進角側においては，
冷却損失割合 $\phi_{\mathrm{w}}$ の増加のために図示熱効率の大きな向 上はみられない。このように, スワールが存在しない 場合にも冷却損失割合が大きい水素燃焼に比べて, メ タノール改質ガス燃焼ではスワールによる冷却損失割 合の増加が著しい，しかし，点火時期を遅角した場合 には冷却損失割合が低下することに加えて，燃焼促進 により発熱等容度が改善されるために，スワールによ る熱効率の向上が可能である.

$3 \cdot 4$ 排気再循環の影響 メタノール熱分解ガスの 燃焼において，排気再循環 (EGR)が排気特性および熱 効率影響因子に及ぼす影響を調べた結果を図10に示す. 実験において設定したEGR割合は $0,10,20 \% て ゙ あ り ，$ 空気過剩率は $\lambda=2.0$, 点火時期は最適点火時期MBTで ある. 図より，EGR割合の増加に伴ってNOx排出量が 効果的に减少するとともに，冷却損失割合 $\phi_{\mathrm{w}}$ が同時に 低下寸るする様子が明らかである，また，EGR割合の 增加に伴って燃焼効率 $\eta_{\mathrm{u}}$ が若干低下寸る傾向があり, その傾向はCO排出量の增加からも分かる. また, $10-90 \%$ 燃焼期間 $\theta_{10-90}$ が若干拡大する傾向が見られる が，最適な点火時期を選択することで発熱等容度 $\eta_{\mathrm{glh}}$ の低下は僅かに抑えられている，一方，この実験で設 定したEGR割合の範囲では，図示熱効率 $\eta_{\mathrm{i}} に$ に変化が 見られない。ここで, 内燃機関の図示熱効率 $\eta_{i}$ と本研 究において解析を行った各熱効率影響因子ならびに 
Ottoサイクルの理論熱効率 $\eta_{\mathrm{th}}$ の間には次の関係が成り 立つ ${ }^{(10)}$.

$$
\eta_{\mathrm{i}}=\eta_{\mathrm{th}} \eta_{\mathrm{glh}} \eta_{\mathrm{u}}\left(1-\phi_{\mathrm{w}}\right)
$$

本実験結果においては，EGR割合增加に伴う混合気中 の不活性ガスの増加による燃焼温度の低下が燃焼ガス から燃焼室壁面への熱伝達量の減少をもたらし冷却損 失割合 $\phi_{\mathrm{w}}$ が低下する一方で, メタノール熱分解ガス中 の水素が持つ高い燃焼速度のために，不活性ガスの導 入による燃焼状態の悪化が小さく抑えられたことによ り, 燃焼効率 $\eta_{\mathrm{u}}$ および発熱等容度 $\eta_{\mathrm{glh}}$ の低下と冷却損失 割合 $\phi_{w}$ の低下が相殺したものと考えられる.

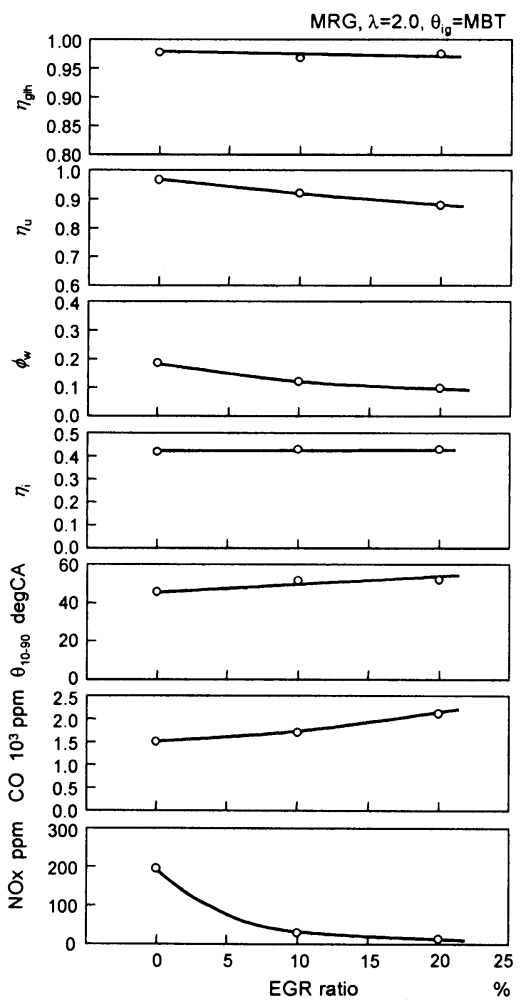

Fig.10 Influence of EGR on thermal efficiency and exhaust emissions in combustion of methanol reformed gas

以上，高い燃焼速度を持つ水素を含むメタノール熱 分解ガスを燃料に用いた火花点火機関においては, EGR ガスを導入した場合にも燃焼状態の悪化が小さく，熱 効率を低下させずにNOx排出量の大幅低減が実現でき る条件が存在することが示される.

\section{4. 結言}

本研究にて得られた結果を以下に要約する.
（1）メタノール熱分解ガスを燃料に用いた火花点火 機関において，スワールによる燃焼室内空気流動の強 化は燃焼効率および発熱等容度を増加させるが，同時 に泠却損失を増加させる傾向がある。

（2）スワールが存在しない場合にも冷却損失割合が 大きい水素燃焼に比べて，メタノール熱分解ガス燃焼 ではスワール導入による冷却損失割合の増加率が大き い. この冷却損失割合増加のため, 運転条件によって は熱効率が低下する場合がある。

（3）充分に希薄な混合気濃度および適切に遅角した 点火時期においては，空気流動強化による燃焼効率お よび発熱等容度の増加が冷却損失割合の増加を上回り, 熱効率が向上する.

（4）空気流動強化による熱効率改善効果は希薄混合 比条件においてとくに大きいため, 熱効率に対する最 適な空気過剩率が希薄化し, 高熱効率と低NOx排出の 両立が可能である.

（5）高い燃焼速度を持つ水素を含むメタノール熱分 解ガスを用いた火花点火機関においては, EGRガスを 導入した場合にも燃焼状態の悪化が小さく，熱効率を 低下させずにNOx排出量の大幅低减が実現できる条件 が存在する。

日産自動車株式会社よりスワール比制御プレートを ご提供頂いた。ここに記し謝意を表す。

\section{文献}

（1）広田，メタノール改質ガスエンジンの研究，自動車技術， 34-10, (1980).

（2）田中・佐藤・阿川, メタノール改質ガスエンジンに関する 研究, 機論, 52-484 B, (1986).

（3）山口・吉田・長家・鈴木・瀨古・堀・金, メタノール改質 ガスディーゼルエンジンの開発研究, 自技論, 36, (1987)

（4）前川・菅原・前田・塩見 · 大和・土屋・大屋，メタノール 改質ガスによる筒内噴射エンジンの研究, 機講論, 97-25, (1997).

（5） 沼田・ 中島 ·首藤・ 山根 - 昼間・高木 - 小松, ハイブリッ ド自動車用メタノール改質ガス機関に関する研究, 自技前 刷, 72-99, (1999).

(6) Tanford, C., Pease, R., Equilibrium Atom and Free Radical Concentrations in Carbon Monoxide Flames and Correlation with Burning Velocities, J. Chemical Physics, 15, (1947).

（7）首藤・二口・中島，水素予混合燃焼機関の熱効率に関する 解析, 機論, 66-644, B, (2000).

（8）首藤・鍋谷・中島, 水素予混合燃焼機関における等容度お よび冷却損失の解析, 自技論, 31-4, (2000).

（9）首藤・鍋谷・中島，インジケータ線図を用いた水素エンジ ンの燃焼解析に関する研究, 機論, 67-654 B, (2001)

(10) List, H. Thermodynamik der Verbrennungskraftmaschinen, Springer, (1939).

（11）首藤・津賀 - 中島, 水素 - 一酸化炭素混合ガスの内燃機関 における燃焼特性, 自技論, 31-4, (2000).

(12) 首藤・津賀，メタノールから得られる $\mathrm{H}_{2}-\mathrm{CO}-\mathrm{CO}_{2}$ 混合燃料 の燃焼および泠却損失特性, 自技論, 32-4, (2001). 